\title{
The Evaluation of Indonesian Labor Market in Optimizing Demographic Dividend in 2016
}

\author{
Siectio Dicko Pratama \\ Statistics Of Lampung Utara Region, Lampung, Indonesia \\ siectio@hotmail.com \\ Rizal Rahadiana \\ Statistics Of Aceh Tenggara Region, Aceh, Indonesia \\ rizal.rahadiana@bps.go.id
}

\begin{abstract}
Considering the structure of its population, Indonesia has the potential to enjoy advantages that are associated with a demographic dividend in the not too distant future. Nonetheless, there are challenges the country is facing, one of which is the coming into being of the ASEAN Economic Community (AEC). This research describes the state of the labor market in Indonesia to identify how best it can benefit from the demographic dividend, including problems, and how to resolve them. The research uses Multiple Linear Regression with backward elimination method. Results of the research indicated that independent variables in the model showed a negative and significant influence on the economy. To that end, working below 15 hours, and unemployment of the educated are the two most important problems facing in Indonesian labor market. Recommended solutions to the problem is to encourage educated unemployed to participate in Micro and Small Manufactures that deal in processing agricultural commodities to become readyto-consumer goods.
\end{abstract}

Keywords: demographic dividend, disguised unemployment, educated unemployed, labor market 


\section{INTRODUCTION}

The establishment of the ASEAN Economic Community (AEC) in 2015 is the realization of the ultimate goal of achieving the vision of economic integration in 2020, which among other goals aims to accelerate and improve economies of ASEAN member states (Chia, 2013). One of the consequences of higher economic integration is an increase in competition, which implies that there is need for enhancing human resources of member states. Thus, the AEC regime, increases the importance and role of quality human resources (Tambunan, 2015). To that, since 2015 a single market that links ASEAN member economies is in place, which implies low import and export cost. To that end, there is need to improve the quality of domestic products to compete with products from other member states in AEC.

Indonesia, as the country that boasts the fourth largest population in the world, draws a lot of interest from many countries, especially other ASEAN member states. Its large market makes it a target from producers of products in other ASEAN member states. That implies that unless Indonesian takes the necessary measures, there is a likelihood that the largest market may only serve interests of other ASEAN countries. To that end, having a large population is very important, but more important for the local economy, is the need to put in place measures to strengthen production capacity in the domestic economy to produce quality goods that will have a competitive edge over other products from other ASEAN member states on one hand, as well as compete in other AEC economies.

Fortunately, the structure of the Indonesian population has huge potential that can be exploited to the benefit of the Indonesian economy. Based on data obtained from the Population Project 2010-2035, published by Statistics Indonesia, Indonesia dependency ratio has been under fifty since 2012 . The implication of that is that the number of people of productive age will be double that of those who fall into the unproductive age bracket (under fifteen and above 65 age groups). This phenomenon is called the De- mographic Dividend. Demographic dividend is a gift with huge potential to contribute to the acceleration of the economy (Hayes \& Setyonaluri, 2015). This is because, with the population of people in the population who are working higher than those who are dependents, country can enjoy higher savings, higher investment, both which contribute to higher economic productivity, faster economic growth and development.

Based on the two facts above, it is clear that since 2016 Indonesia, which is a member of the newly established AEC, has been experiencing a demographic dividend. Labor is one of the meeting points between the ASEAN Community and the demographic dividend, because the latter creates surplus labor, which if well prepared can enable the country to reap the benefits that are associated with being a member of the former. Thus, the best way the Indonesian economy can derive benefits from AEC is by improving the quality of its human resources (labor market), which to a large extent depends on the quality of the country's population in the productive age bracket. Thus, the overreaching goal of this research was to determine the extent to which productive age population is having an effect on the labor market in Indonesia. In that backdrop, the objectives of this research were 1) to describe the composition of Indonesian labor market, 2) to identify key problems affecting the labor market, and 3) to identify the best solutions to key problems affecting the Indonesian labor market.

\section{Key Issues affecting the Indonesian Labor Market}

The 13th International Conference of Labor Statisticians (ICLS) propounded a concept that has since become the basis used in compiling labor market indicators in the world. There are at least three basic indicators that are used in conducting labor analysis, inter alia, labor force, employment and unemployment.

Labor force refers to all people who are of working age both employed and unemployed. Meanwhile, the employed population refers to people who are aged fifteen and older, who are working and earn wages from their labor within a week. To that end, 
people who are temporarily absent from their jobs because of waiting harvest, injury, illness or a vacation are classified as employed. The unemployed population refers to people who are not currently working and are not looking for a job, do not have any intension to establish their own business, exhibit hopeless in gaining gainful employment or have been accepted for a job but have yet to begin working (International Labour Organization, 1982)

Manpower has a strong relationship with a country's human resources. With respect to some of the main issues affecting manpower in Indonesia, a key official in the Ministry of Manpower and transmigration identified three, which include quality, quantity and the distribution of manpower. The quality of human resources is strongly related to education, productivity and wages. Productivity also affects the quantity of workers. Meanwhile, manpower distribution, relates to the fact that agriculture is still the largest source of employment for Indonesian population (Kementerian Keuangan, 2018).

\section{Impact of Demographic Dividend on Eco- nomic Growth}

Demographic Dividend is a demographic transition that is characterized by the condition whereby the growth of the working age population is faster than that of the total population, which can be discerned from the trend of the dependency ratio. The decrease in the dependency ratio, implies that the proportion of the population that falls under the under 15 areas and older than 64 years is smaller than the population that falls under 15-64 years old age bracket. That leads to a situation whereby the productive age population is larger than the dependents (under 15 and over 64 years old population). It is the potential that a country that has a larger productive age population than dependents can contribute to economic improvement, which is also referred to as the demographic dividend (Marone, Heloisa, 2016).

Based on neo-classical growth model, which was introduced by Solow (1956), high population growth undermines economic growth due to the capital dilution effect. Nonetheless, subsequent research on the subject showed that it is not population growth that affects economic growth, but change in age structure of the country's population. A study that regressed GDP per capita growth rate on the growth rate of the working age population and the growth rate of total population, produced a positive and significant effect (Feng \& Mason, 2005). Prskawetz et al., (2007) also showed that the demographic dividend occurred at a time when the baby boomer generation entered the labor market, because of the higher rate of growth of the working age population than growth of the total population. Such a condition leads to growth in output per capita or productivity.

A research by Adeyeye (2015) on Manpower Development and Economic Growth in Nigeria concluded that investment in education increases labor capacity. This is attributable to the fact that expenditure on education contributes to human capital improvement, which in turn positively affects economic growth. Therefore, for a country to accelerate economic growth, it should restructure its educational system. Meanwhile, Diar (2017) in a study on factors that influence economic growth in Indonesia between 1986-2014 showed that unemployment and investment have positive effect on economic growth. Thus, the research underscored the importance of manpower in economic growth. Robert, Library \& Yang (1967) corroborated the finding that an economy will face economic stagnation if it does not implement necessary and appropriate manpower improvement and development policies. Higher human resource quality triggers an increase in consumption and production, which in turn contributes to growth in income per capita. Two good examples are China and Japan. Japan and China used to import most of their equipment from abroad in the past, but later implemented policies that increased the quality of its manpower by among others, sending some members of their population abroad. Consequently, enhancement in the quality of manpower has since propelled rapid increase in economic productivity, higher wages, and higher per capita incomes. Today, both Japan and China are powerful economic powerhouse in the World. 


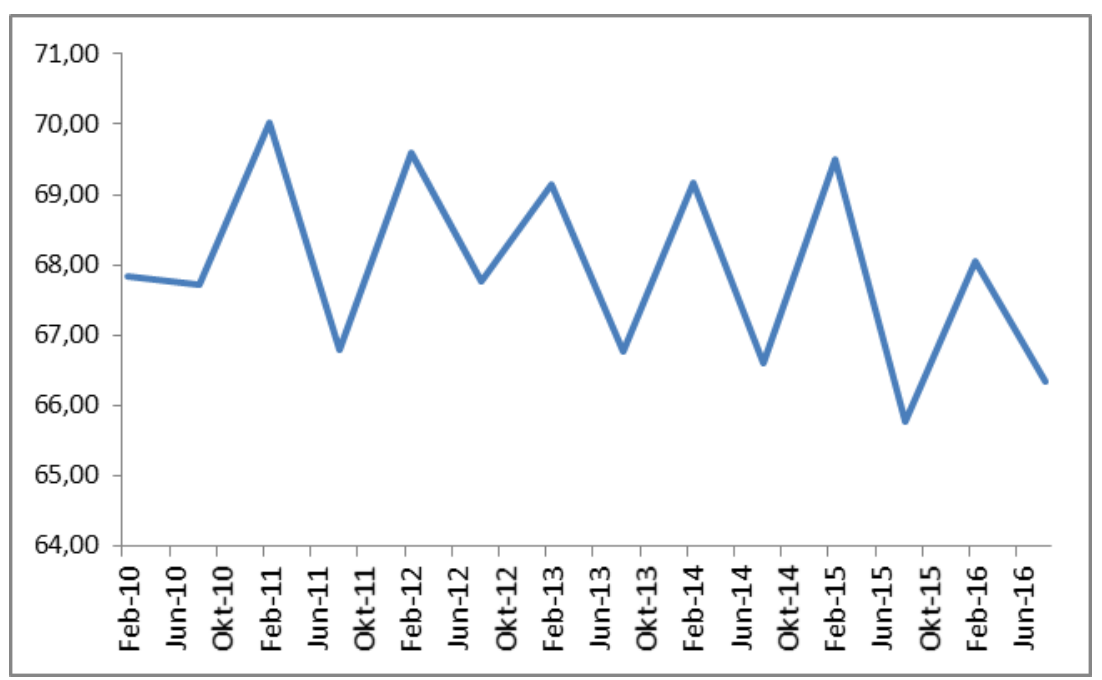

Figure 1. Society, Academia and Government Nexus Source : Data analysis

\section{METHODS}

This research used descriptive statistical analysis of the labor market condition in Indonesia in 2016, which was supplemented by backward elimination multiple linear regression model to identify the key problems affecting the Indonesian labor market. Multiple Linear regression (Timm, 2002), consisted of the Gross Domestic Product (GDP) in the third quarter in 2016 as the dependent variable, and five independent variables that comprised labor market indicators. The five independent variables included average labor wages, which describes the quality of the labor; workers who are employed for below fifteen hours which represents worker productivity; people who have above high school education but are facing open unemployment and unemployment, to represent potential workers (quantity and quality); and also percentage of workers employed in the agricultural sector to total labor force to represent contribution of agricultural employment in total labor force. The variables was limited to date for August 2016 as reported and published in "The Laborer Situation in Indonesia 2016" (BPS-Statistics Indonesia, 2016b) and "Indicators of The Labor Market in Indonesia 2016" (BPS-Statistics Indonesia, 2016a).

\section{FINDINGS AND DISCUSSION}

\section{The Condition of the Labor Market in In- donesia}

Indonesian labor force shows a trend that fluctuates during 2010-2016 period (Figure 1). Nonetheless, it is evident that there is an annual pattern which is characterized by an increase in labor force in February and a decrease in August. A closer look at labor force data by main industry, shows that the pattern of an increase in labor force in February and a decrease in August is very apparent in the agricultural sector. The implication of that is that the agricultural sector is the main source of employment for Indonesian labor force, which is why seasonal fluctuations in the sectors are reflected in the pattern of the entire Indonesian labor force. The seasonal variation in the labor force in the agricultural sector is because in February most farmers are involved in harvesting their plants crops such as rice and corn, which absorbs a lot of manpower.

If we observe the month-to-month trend (Figure 1), the labor force decreases during February 2010-February 2016. Although the percentage of people aged above 15 years and 64 years continues to grow, working age population in February 2016 


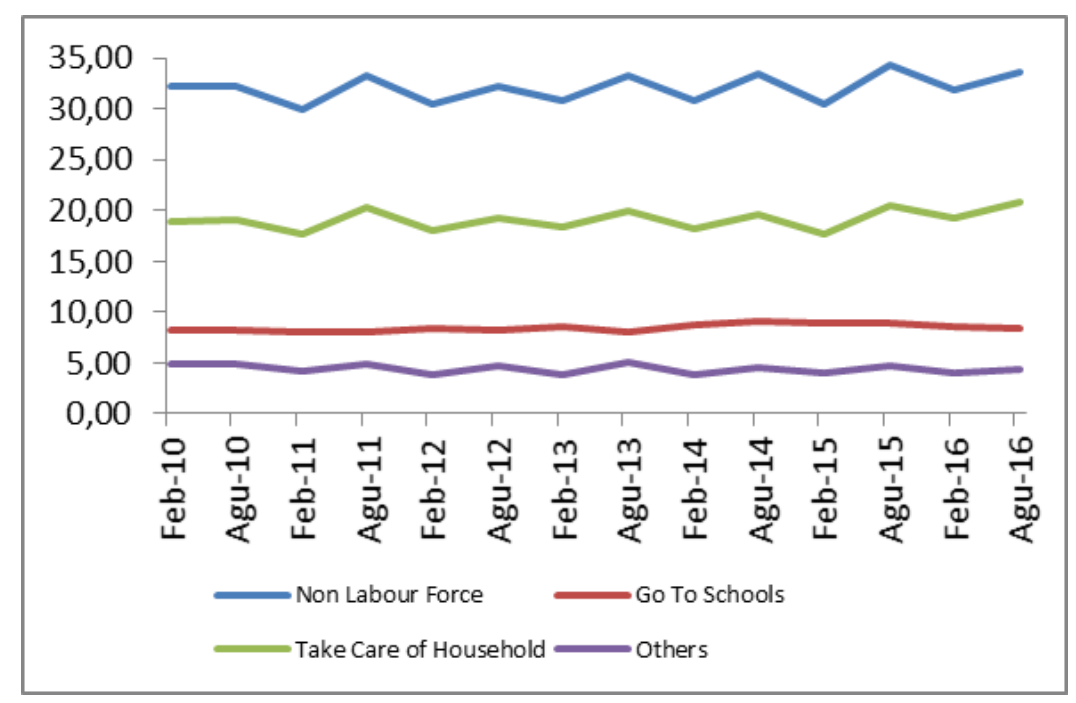

Figure 2. The Percentage of Non-Labor Force Based on The Activites in Indonesia between 2010 2016

Source : Data analysis

was the lowest compared to previous years. This means that there is a tendency for some members of the labor force not to be involved in gainful employment such as providing home making services, attending higher education and training, and other activities.

The trend in non-labor force employment shows that a pattern that is akin to household activities (Figure 2). In other words, the pattern of non-labor force employment is strongly influenced by employment in household activities. It is worth remembering that the pattern also fluctuates as is the case with employment in the agricultural sector. One of the reasons is that during harvest in February, women who generally work on household activities get involved as well. This explains the decrease in non-labor force employment during February.

Figure 2 shows that the trend in the number of people who attend school has been rising since 2012 before in decreased slightly in 2016. On the contrary, people who are involved in other activities increased in 2016. The rise in not attributable to developments in the trend of people involved in other activities, as the pattern is similar to that exhibited by non-labor force employment. This indicates that there is a shift or movement of people who are employed in other activities. Such activities may involve leisure. Based on an article written by Fau, Rizal, Fin, \& Rachman (2017), there is shift in recreation activities that starts in the second quarter of 2015 and ends in 2017. Such an argument is corroborated by other data that shows that Indonesians show increasing preference to consume leisure by traveling and other leisure activities such as shopping. This phenomenon particularly affects young people the most as they are fond of enjoying leisure instead of searching for jobs.

Based on Figure 3, the trend of people attending school has been increasing during 2012-2016 period. Nonetheless, despite the decrease, the percentage of people attending school during 2012-2016 period, is still higher than that for years prior to 2012 . That development attests to the demographic dividend phenomenon which begun in 2012 . That said, starting with 2016, there is a down ward trend in the number of people attending school. It takes between three and four years for people who achieved primary education in 2012 to join the labor force in 2016. However, that does not happen. To that end, the phenomenon may be attributable to the behavior of people to shift from working to leisure (as explained earlier), especially 


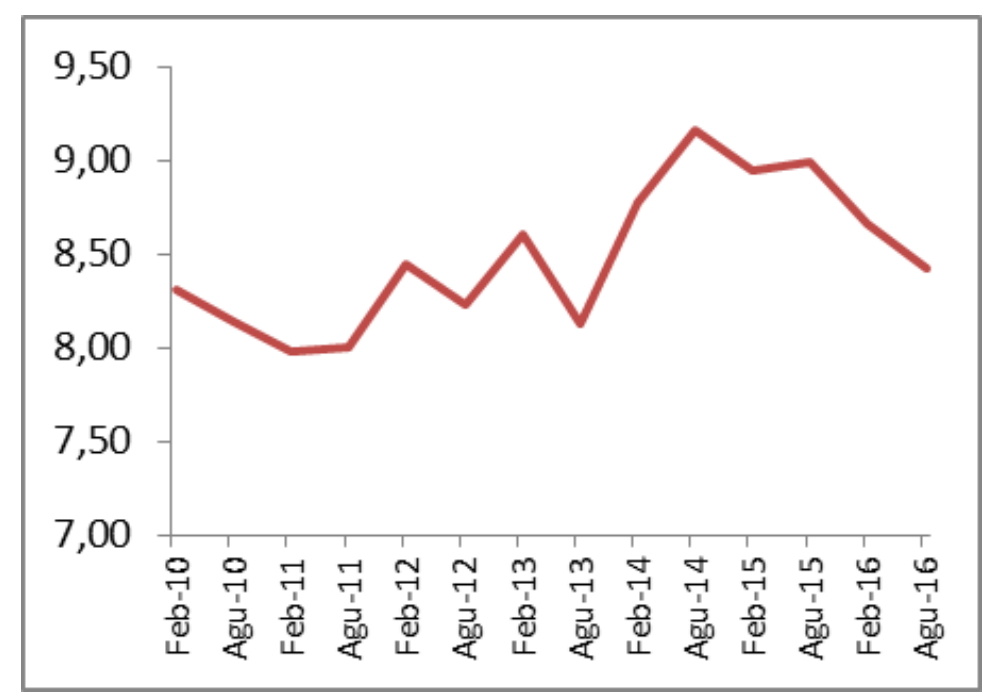

Figure 3. The Percentage of People Who attend School in Indonesia between 2010 - 2016 Source : Data analysis

young people who have higher preference for travelling activities. In other words, if the increase in the number of people of productive age ends up feeding into leisure activities instead of joining the labor force, Indonesian will not derive anticipated benefits from the demographic dividend. That is why there is need for the Indonesian government to take action.

\section{The Labor Market Equation}

The best equation which is produced in this research is as followed:

$$
\begin{gathered}
\tilde{Y}=21,86-0,85 X_{1}^{*}-1,01 X_{2}^{8} \\
\text { Where- }(1,13)(0,5)(0,4) \text { by : }
\end{gathered}
$$

$\mathrm{Y}=$ GDP based on constant price in the third quarter 2016

\section{$\mathrm{X} 1=$ Percentage of under fifteen hours' workers}

$\mathrm{X} 2=$ Percentage of the unemployed with high education

The equation above has been proved to be robust statistically because it fulfills all the multiple regression assumptions. Data normality assumption has been met, based on the histogram that attested to data normality with an average 0 and variance 1 . In addition, data trend is free from heteroscedasticity as attested by scatter plot of the prediction value and the residual that does not show a specific form. Moreover, the Glejser test, showed that the error from the equation was constant, which proved that there was no heteroscedasticity in the data. Tests also showed that the data series were free from serial correlation. This was proved by the Durbin Watson (DW) test that had the value of 1,495 . The magnitude of the $\mathrm{DW}$ test statistic was within the range of dU-4du for the 1 percent significant error. In addition, VIF of each variable falls below 5 which attested to absence of serial correlation among independent variables. Thus, the model specification fulfilled all the multiple regression assumptions.

Overall Test showed that all the independent variables simultaneously had significant influence on the dependent variable. The R2 Adj value is 0.304, which means that all the independent variables are able to explain 30.4 percent variance of the dependent variable, leaving the remainder of the variance (1-0.304) unexplained by the model. Meanwhile, partially, each variable has significant influence on the dependent varia- 


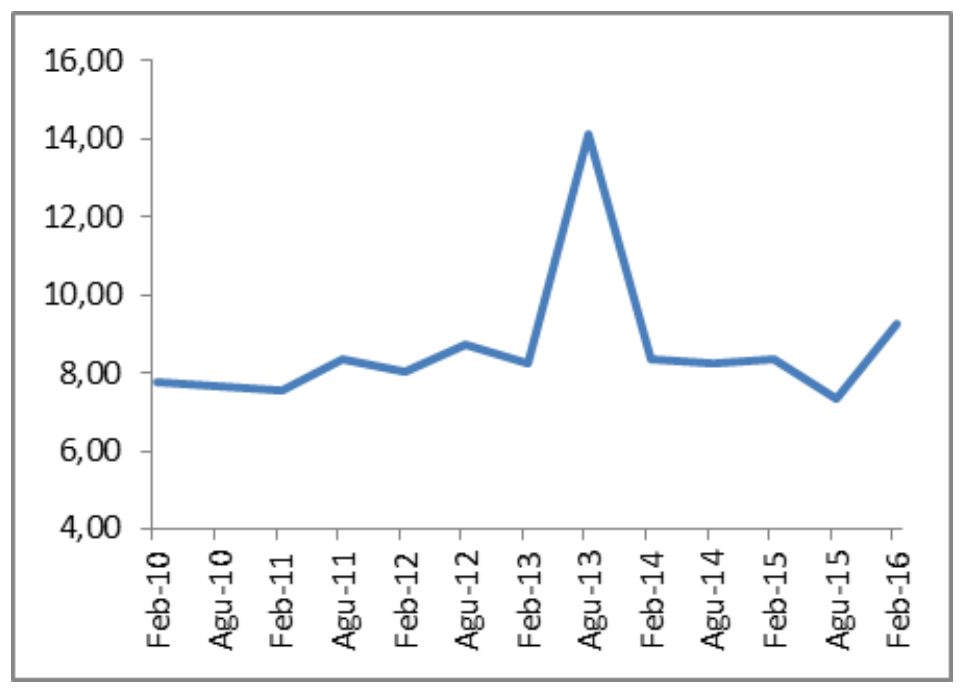

Figure 4. Percentage of The Under Fifteen Hours Workers in Indonesia during 2010-2016 period Source : Data analysis

ble. The under fifteen hours-worker's variable significantly influence GDP only at the 10 percent level of significance, while the variable of educated unemployed has significant influence on GDP at 5 percent level of significance. An increase in the variable of educated unemployed by 1.01 percent induces an increase in GDP by as much as one million rupiahs. Meanwhile, an increase of 0.85 percent in the under fifteen-hour workers induces an increase the GDP by one million rupiahs.

As the other variables in the model were not significant, they were removed from the model. Thus, the two variable mod$\mathrm{el}$ is the best equation for the Indonesian labor market, inter alia, the percentage of under fifteen-hour workers variable and the percentage of educated unemployed variable. Other variables were removed from the model (average labor wage, the percentage of the agricultural workers and open unemployment variables).

\section{Disguised Unemployment}

Disguised unemployment according to Robinson (1973) in Majid (2012) refers to a condition whereby workers are employed on jobs that do not march their skill level and capabilities. According to the United $\mathrm{Na}$ - tions (Ducoff \& Hagood, 1957), disguised unemployment reflects a state of underunemployment. In other words, disguised unemployment is one manifestation of under -unemployment. Meanwhile, under unemployment itself refers to a condition where the number of hours a worker serves is lower than the optimum. To that end, determining disguised unemployment can be done by identifying workers who work for hours that are lower than the optimum. Based on results of this research, it is evident that the rise in the number of workers who are employed for less than a weak contributes to lower economic growth. This is because workers who are employed for less than fifteen hours in a week do not contribute to the economy in accordance with their potential. In other words, workers serving for less than fifteen hours reflect attest to low productivity that in turn undermines economic growth and development.

Based on Figure 4, it is apparent that trend of people working for less than 15 hours is constant but experienced a steep decrease in August 2013, when the percentage reaches fourteen percent. The steep decrease was attributable to the fact that labor survey was conducted in the fasting month of Ramadhan, a time when many workers reduce the number or workers they serve while some chose not to work at all. This develop- 


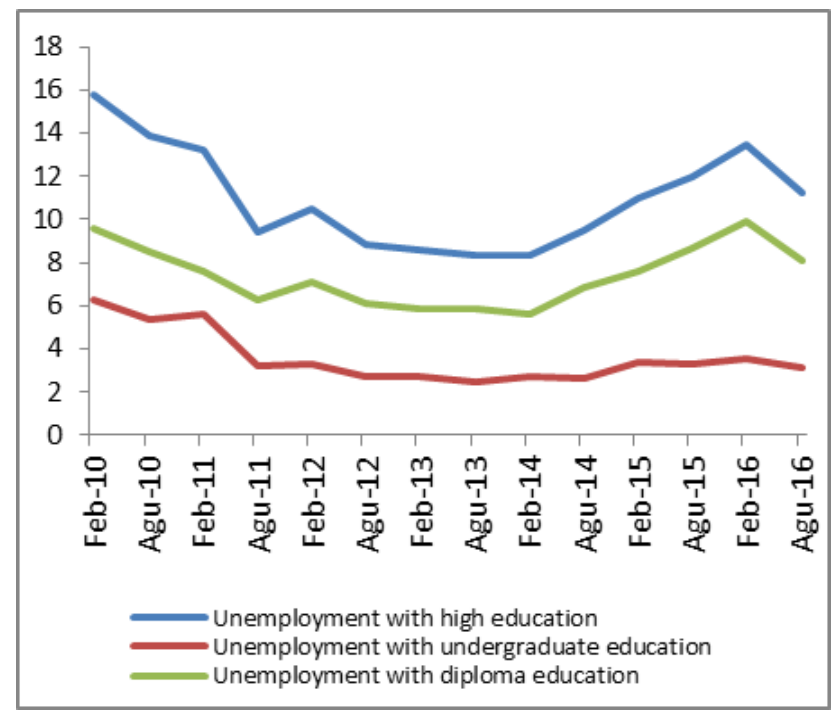

Figure 5. The Percentage of Unemployment Based on Education attainment in Indonesia (2010 - 2016)

Source : Data analysis

ment also underscores the reality that Indonesian labor force has a large percentage of workers who are employed in the informal sector where they can choose to reduce the number of hours they serve or decide not to work at all. Informal employment is more flexible than formal employment.

An even in-depth analysis of the Indonesian labor market shows based on BPS report on labor in Indonesia titled, "The Laborer Situation in Indonesia August 2016", it becomes apparent that the number of workers working for less than fifteen hours, fall under the 25-29-year-old age bracket, and are mostly employed in the agricultural and services sectors. In Indonesia, people who are employed in the agricultural sector and services sectors (especially the informal sub sector), are generally low skilled. Nonetheless, given the fact that most workers who work for less than 15 hours fall under the 2529 old age bracket, underscores the potential through training and skill enhancement. With more training, such workers will be able to enhance the contribution they make toward the economy. Besides, the government can increase job opportunities in areas that employ low skilled labor as well as create opportunities for such labor to enhance their development through on job training exercises.

\section{Educated Unemployment}

The problem of educated unemployment is another issue that today characterizes Indonesian labor force. Apparently, the problem of educated unemployment has an even larger effect on the economy than that attributable to underemployment (workers working less than fifteen hours a week). The existence of high educated unemployment reflects a weakness in the labor market in absorbing skilled workers. Besides, high educated unemployment also attests to the fact that the Indonesia is not taking advantage of the demographic dividend as it should. To that end, there is need for the government to devise ways of identifying the underlying causes of the problem so that the economy can derive the benefits that are associated with the demographic dividend.

The percentage of people who have high education attainment but are also unemployed showed a downward trend during 2010-2013 period but has since 2014 reversed to an increase (Figure 5). Thus, despite a slight decrease by the end of 2016, the rate of unemployment of people with high education attainment has been increasing since August 2014. One possible reason for the upward trend in educated unemployment is the moratorium the government imposed on recruitment of civil servants which has been place since 2015 . The same policy 
Siecto Dicko Pratama,Rizal Rahadiana - The Evaluation of Indonesian Labor Market ....

Table 1. The Percentage of The Workers Based on The Business Field and Their Last Education in Indonesia in August 2016

\begin{tabular}{|c|c|c|}
\hline Business Field & Diploma & Undergraduate \\
\hline 1 Agriculture, Plantation, Forestry, Hunting and Fisheries & 0,39 & 0,90 \\
\hline 2 Mining and Excavation & 1,62 & 5,84 \\
\hline 3 Industry & 1,62 & 3,91 \\
\hline 4 Electricity, Gas and Drinking Water & 8,08 & 16,36 \\
\hline 5 Construction & 1,01 & 3,24 \\
\hline 6 Trade, Restaurants and Accommodation Services & 2,88 & 5,15 \\
\hline 7 Transportation, Warehousing and Communication & 2,36 & 6,48 \\
\hline 8 Finances, Real Estate, Leasing and Corporate Services & 9,28 & 35,13 \\
\hline 9 Social Services, Social and Individual Services & 8,50 & 34,73 \\
\hline Total & 2,88 & 9,36 \\
\hline Variance & 10,31 & 145,86 \\
\hline
\end{tabular}

Source : Data analysis

was in effect during 2011-2013 period. Based on figure 5 , the moratorium policy seems to have contributed to an increase in educated unemployed. To that end, the effect of the imposition of a moratorium on recruiting civil servants has been an increase in the percentage of educated unemployed as people with high education attainment tend to prefer working in civil service, state owned enterprises and in the private sector. This fact also underlies the high percentage of people with high education attainment who are employed in the four sectors, inter alia electricity, gas, drinking water; finances, real estate, leasing and corporate services; and social services, social and individual services.

Nonetheless, a closer look at the composition of the educated unemployment (Figure 5), reveals the fact that the pattern of the educated unemployment is similar to the pattern of those people who are uneducated and have under graduate education. Meanwhile, the percentage of educated unemployment for diploma holders, is relatively stable. To that end, the sub sector of educated manpower that is problematic is people who have higher education other than diploma holders, which is the focus of the analysis in this research.
Based on Table 1, it is evident that most of the labor force in Indonesia is employed in sectors eight and nine above. The distribution data for workers holding diplomas is smoother than that for educated workers with non-diploma and under graduate education. The variance of data also underscores the difference in variability between data for diploma holders and nondiploma holding under graduate workers. The variance of workers with diploma education is smaller than that for non-diploma holding under graduate educated workers, 10.31 and 145.86, respectively. The smaller variance for workers with diplomas than that for workers with non-diploma under graduate education is due to the relatively even distribution of the former in almost all economic activity compared with the latter. The underlying factor for that may be the curriculum used in diploma education that is compatible and suitable to skillsets that are required in various economic activities. On the contrary, the specialized and theoretical nature of curricula used in non-diploma under graduate education makes them inappropriate for employment in other economic activities than the few activities where such specialized skills meet job requirements.

Based on Table 2, 25.51 percent of the educated unemployed were categorized em- 
Table 2. The Percentage of Workers with High Education Based on Job Status in Indonesia in August 2016

\begin{tabular}{lc}
\hline \multicolumn{1}{c}{ Employment Status } & Workers \\
\hline 1 Self employed & 4,18 \\
2 Employer assisted by part time/unpaid workers & 3,12 \\
3 Employer assisted by permanent/paid workers & 17,74 \\
4 Employees & 25,51 \\
5 Agricultural freelance & 0,24 \\
6 Non agricultural freelance & 0,46 \\
7 Family or unpaid workers $\quad$ Total & 3,35 \\
\multicolumn{1}{c}{$\quad 12,25$} \\
\hline
\end{tabular}

Source : Data analysis

ployees, followed by employer assisted by permanent/paid workers (17.74 percent). To that end, if the state of employment continues to be as depicted in Table 2, solving unemployment problem will be difficult to achieve. The educated unemployed must be trained and educated in such a manner that they have the requisite skills to work in various economic activities. Achieving that requires introducing changes in the education curriculum for non-diploma under graduate education, to make skills learned in high education relevant and on demand on jobs in the labor market.

\section{The Development of Agroindustry by Young People}

Economic transformation as postulated by Breisinger and Diao (2008) has at least three main points: 1) fundamental economic structure changes that are reflected in the increasing importance of the industrial sector and decrease in the contribution of the agricultural sector to the economy; 2) a decrease in the number of workers employed in the agricultural sector and an increase in workers employed in industry and services sector. Nonetheless, the decrease in the labor force employed in the agriculture sector tends to be slower than the decrease in the share of the agricultural sector to GDP; and 3) a significant increase in the urbanization rate that is followed by a shift in centers of economic growth from rural to urban areas (Breisinger \& Diao, 2008). It is important to note that economic transformation induces a fundamental change in the share of the agricultural sector in terms of contribution to GDP and labor force. Wise management of the process can promote economic development, while failure to do so in others, creates low economic growth traps that are characterized by a decline in the share of agricultural sector to the economy while at the same remains major source of employment for the population.

Based on Figure 6, the share of the agricultural sector in the GDP has been declining during 2000-2014, while that for the service and industrial sectors has shown an upward trend. Since 2007, the service sector has become the largest contributor to GDP. The trend is not unexpected and must be welcome since it is typical of an economy that is undergoing transformation from depending on agriculture to manufacturing and services sectors. The problem, however, is that in the case of Indonesian labor market, the trend in labor shows a shift from the manufacturing sector to agriculture and services sectors (Figure 7). The pattern of labor movement reflects the growing importance of the services sector as both the largest contributor to the economy and major source of employment. While that would not be problem if services sector activities had high value added and quality jobs as the case in developed countries, it is a problem in Indonesia because the services sector largely comprises informal sector activities that employ 


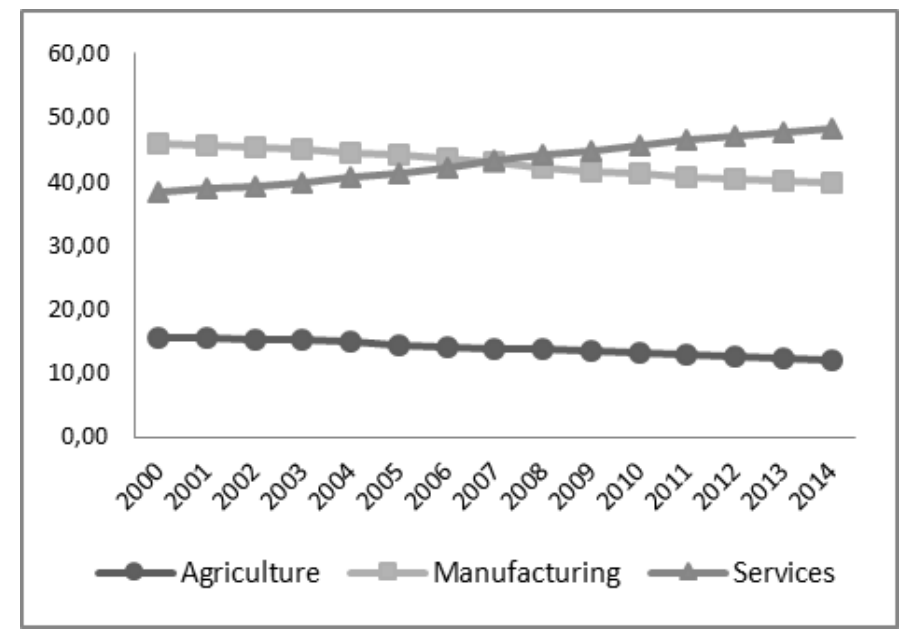

Figure 6. The Development of GDP in Three Main Business Field in Indonesia Between 2000-2014

Source : Data analysis

low skilled labor. That means that the economy will not benefit from the demographic dividend as long as the services sector remains the major source of employment for the productive age population.

Thus, for Indonesia to derive benefits from the demographic dividend, it must emulate the experience of developed countries that focused their development efforts on developing the manufacturing sector which induced improvement in the agricultural sector through back ward linkages as well as spurred productivity enhancement that led to movement of labor from the agricultural sector to industrial sector, fueled quality urbanization, and eventually the development of quality services sector. Today, the manufacturing sector is experiencing contraction in both contributions to GDP and employment, which is having a negative impact on the absorptive capacity of the economy, and by extension, ability to produce processed and final products. If such a trend continues, Indonesia faces the grim prospect of becoming a market for products that are produced in other countries, and the death of the source of economic productivity and production-industrial sector.

To that end, to prevent that scenario from occurring, there is need for the Indonesian government to design and implement a policy that emphasizes the development of agro-industry production, with the focus placed on micro, small and medium enterprises (MSMEs). The policy, if implemented, will increase economic production from the micro level, achieve inclusive and equitable growth objectives, reduce poverty and inequality through higher labor absorption at both the household level and in rural areas. In addition, increase in production of agroindustry MSMEs will contribute to higher local and domestic GDP, incomes, productivity, and welfare of producers, workers, local and national economy. All of those will lead to better welfare.

The involvement of young people in agro-industry development will also spur innovation in production processes, intermediate products that will be sold to industries for further processing, as well as final products that will be sold to final consumers. The increase in economic activities will contribute to more jobs for educated unemployed, thereby enabling the economy to benefit of demographic dividend that is currently underway.

Some good examples of agro-industry activities that have been initiated and developed by educated youth include one that is managed by Firmansyah, which uses interesting designs and product promotion techniques to process and package cassava chips that are sold to retailers in many parts of In- 


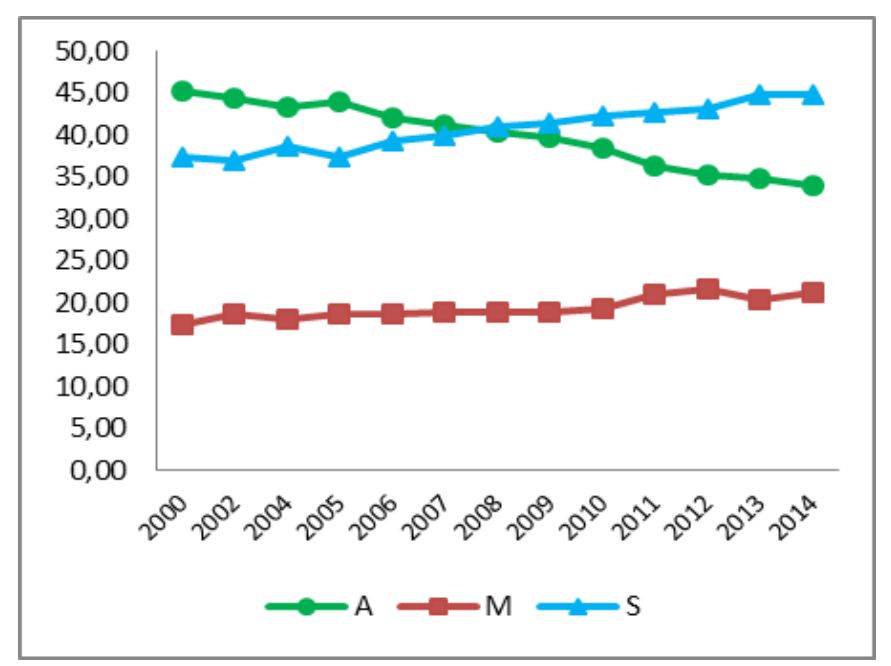

Figure 7. The Percentages of the Man Power in Three Main Business Field in Indonesia (20002014)

Source : Data analysis

donesia (Wartawirausaha, 2014). Rofif, is another young entrepreneur, who operates a cafe that produces banana cakes, drinks and ice cream. Today, the business employs 20 employees (DetikFinance, 2017). To harness the vast unexploited potential, government should conduct of mapping of the potential of the agro-industry, with respect to the raw materials needed, existing state of raw materials required and possibility for expansion and growth in future, and how best to ensure that suppliers of raw materials are linked to small and medium size agro processors and producers. Such a policy will help to ensure the continual available of raw materials that agro producers need to operate their business now and in future.

Conducting competition for funding is one of the ways that can cultivate the interest of the youth in agro-business activities. Such competition should take the form of submission of agro-business proposals with winners awarded seed capital and technical assistance and supervision to implement their business proposals. Such activity entices and motivates young people to come up with creative ideas in the field of agroindustry. That way, the educated youth will contribute to the growth and development of agro-industry activities that will turn increase employment activities, incomes, and purchasing power. With higher purchasing power coming from agro-industry activities, will create spillover effects to other sectors of the economy such as manufacturing, transportation, and financial and tourism services sectors. That way, agro-industry policy by empowering MSMEs, will not only increase the contribution productive age population contribute to local and national economy, but more importantly, will reduce underemployment and unemployment of both the educated and uneducated youth, mitigate poverty and income inequality, which by implication will enable Indonesia to take advantage of the demographic dividend.

\section{CONCLUSION}

Agriculture is still the dominant source of employment in Indonesian economy. This is reflected in the trend of the labor force in Indonesia, which shows an increase in February and a decrease in August of each year. Nonetheless, the demographic dividend, which has been touted for having various economic benefits for the economy, is yet to have such anticipated impact on the labor force. One of the problems, is the preference of the youth to spending a lot of their useful time travelling for entertainment purposes, forsaking searching for gainful employment. Such behavior constitutes a major 
obstacle that continues to stand in the way for the country to take advantage of the demographic dividend. On the contrary, the youth, are prolonging the dependency burden on the economy.

Based on the quantitative model, two key variables explain the Indonesian labor market, inter alia, the under 15 -hour workers variable and educated unemployed variable. The influence of the educated unemployed variable is larger than that of the under 15hour workers variable on GDP. A decrease of 1.01 percent in educated unemployed variable, induces an increase of one million rupiah in GDP. Meanwhile, for the under 15hour workers variable has significant influence on GDP at 10 percent significance level. A decrease of 0.85 percent in the under 15-hour workers variable induces an increase one million rupiah in GDP.

The variable of workers working under 15 hours, comprises low skilled workers who fall under the 25-29 age bracket, and employed largely in informal services and agricultural sectors. To that end, the policy to empower them to work should encompass provision job skills that are appropriate to enable them to participate in gainful employment. Meanwhile, for the educated unemployed, tend to prefer employment in the public sectors where job security is assured. To that end, moratorium on the recruitment of civil servants which is still in place since 2015 has in part played an important role in the high unemployment rate. To reduce unemployment of the educated youth, requires efforts and programs that orient them toward entrepreneurship in MSMEs agro-industry activities.

However, there are areas for further research in this area. One area that needs further research is the behavior of leisure activities that continue to attract a good proportion of young people. The importance of the research lies in the fact that its results will help to shed more light on mitigating the problem as a way to enable the economy to benefit from the ongoing demographic dividend. Research on the problem of manpower development and how that affects the economy, is an equally important area for further investigation.

\section{REFERENCES}

Adeyeye, T. C. (2015). Manpower Development and Economic Growth in Nigeria. Journal of Economics and Sustainable Development, 6(9), 26-35

BPS-Statistics Indonesia. (2016a). Indikator Pasar Tenaga Kerja Indonesia Agustus 2016. Jakarta: BPS-Statistics Indonesia.

BPS-Statistics Indonesia. (2016b). Laborer Situation in Indonesia Agustus 2016. Jakarta: BPS-Statistics Indonesia.

BPS-Statistics Indonesia. (2017, July 3). Penduduk 15 Tahun Ke Atas yang Bekerja menurut Lapangan Usaha 1986 -2017. Retrieved from https:// www.bps.go.id/ statictable/2009/04/16/970/penduduk15-tahun-ke-atas-yang-bekerja-menurut -lapangan-pekerjaan-utama-1986--2018.html

Breisinger, C., \& Diao, X. (2008, November). Economic Transformation in Theory and Practice: What are the Messages for Africa?. https:// www.researchgate.net/ publication/24110301_Economic_Transformat ion_in_Theory_and_Practice_-_What_are the

Chia, S. (2013). The ASEAN Economic Community: Progress, Challenges, and Prospects. Retrieved from https:// www.adb.org/sites/default/files/ publication/156295/adbi-wp440.pdf

DetikFinance. (2017, March 12). Buka Cafe Serba Pisang, Rofif Bisa Raup Omzet Rp 80 Juta Sebulan. Retrieved from https://finance.detik.com/solusiukm/d3444774/buka-cafe-serba-pisang-rofifbisa-raup-omzet-rp-80-juta-sebulan? $\mathrm{ga}=2.34505768 .864645267 .15559312$ 06-553448713.1555931206

Diar, D. T. A. (2017). Analisis FaktorFaktor Yang Mempengaruhi Pertumbuhan Ekonomi Di Indonesia Tahun 1986-2014. Fakultas Ekonomi Dan Bisnis Universitas Muhammadiyah Surakarta. Thesis on Universitas Mudammadiyah Surakarta: Unpublished 
Ducoff, L. J., \& Hagood, M. J. (1957). The Meaning and Measurement of Partial and Disguised Unemployment. Retrieved from http://www.nber.org/ chapters/c2641

Fau, T. N., Rizal, Fin, H., \& Rachman, F. (2017, November 14). Leisure Economy, Antara Perubahan Konsumsi, Disrupsi dan Potensi. Retrieved from http://validnews.co/-Leisure-Economy--Antara-Perubahan-Konsumsi-Disrupsi-dan-Potensi-rdu

Feng, W., \& Mason, A. (2005). Demographic Dividend and Prospects for Economic Development in China. United Nations Expert Group Meeting on Social and Economic Implications of Changing Population Age Structures. Mexico City, Mexico: United Nation. Retrived from http://www2.hawaii.edu/ amason/ Research/Wang\%5B1\% 5D.Mason.2006.pdf

Hayes, A., \& Setyonaluri, D. (2015, April). Taking Advantage of the Demographic Dividend in Indonesia : A Brief Introduction to Theory and Practice. Retrieved from https:// indonesia.unfpa.org/sites/default/files/ pub-pdf/

$\mathrm{Bu}-$

ku_Policy_Brief_on_Taking_Advantag e_on_Demographic_Dividend_02c_\% $2 \overline{8} 2 \% 29 \_0 . p d f$

International Labour Organisation. (1982). Statistics of Labour Force, Employment, Unemployment and Underemployment (Report II ICLS/13/II). Geneva: International Labour Office

Kementerian Keuangan. (2018, March 1). Tiga Isu Utama SDM Indonesia dalam Angkatan Kerja. Retrieved from https:// www.kemenkeu.go.id/publikasi/berita/ tiga-isu-utama-sdm-indonesia-dalamangkatan-kerja/

Majid, N. (2012). How Not to Count the Employed in Developing Countries. Retrieved from https://www.ilo.org/ wcmsp5/groups/public/---ed_emp/ documents/publication/ wcms_203524.pdf
Marone. Heloisa. (2016). Demographic Dividends, Gender Equality, and Economic Growth: The Case of Cabo Verde. IMF Working Paper Series WP/16/169. Retrieved from https://www.imf.org/ external/pubs/cat/longres.aspx? $\mathrm{sk}=44178.0$

Prskawetz, A., Fent, T., Barthel, W., CrespoCuaresma, J., Lindh, T., Malmberg, B., \& Halvarsson, M. (2007). The Relationship between Demographic Change and Economic Growth in the EU. Institut Für Demographie: Research Report 32. Retrieved from https:// www.oeaw.ac.at/fileadmin/subsites/ Institute/VID/PDF/Publications/ Forschungsberichte/FB32.pdf

Yang, W. (1967). Human Resource as the Key Factor of Economic Development. Atlanta University: Thesis. Retrieved from http://digitalcommons.auctr.edu/ cgi/viewcontent.cgi? article $=2326 \&$ context $=$ dissertations

Solow, R. M. (1956). A Contribution to the Theory of Economic Growth. The Quarterly Journal of Economics, 70 (1), 65-94. Retrieved from http:// www.jstor.org/stable/1884513

Tambunan, T. T. H. (2015). Perekonomian Indonesia: Era Orde Lama Hingga Jokowi. (R. Sikumbang, Ed.) (Pertama). Bogor: Ghalia Indonesia

Timm, N. H. (2002). Applied Multivariate Analysis. Springer Texts in Statistics.

Retrieved from https:// www.springer.com/gp/ book/9780387953472

Wartawirausaha. (2014, September 28). Firmansyah Budi Prasetyo, Sarjana Yang Sukses Jadi Pengusaha Kripik Singkong. Retrieved from http:// wartawirausaha.com/2014/09/ firmansyah-budi-prasetyo-sarjana-yang -sukses-jadi-pengusaha-kripiksingkong/\#ixzz4zMnS4Sjm 